\title{
PERTUKARAN SUMBERDAYA MULTI-AKTOR DALAM MITIGASI BENCANA
}

\section{Multi-Actor Resource Exchange in Disaster Mitigation}

\author{
Avrina Dwijayanti \\ Pusat Pelatihan dan Pengembangan dan Kajian Manajemen Pemerintahan \\ Lembaga Administrasi Negara \\ Jl. Raya Baruga No. 48, Kota Makassar \\ E-mail : avrina.dwijayanti@lan.go.id \\ Zarni Adia Purna \\ LaDem Institute, Kota Makassar \\ E-mail : Hexatanic88@gmail.com
}

Naskah diterima tanggal 23 Agustus 2019. Naskah direvisi tanggal 1 September 2019. Naskah disetujui tanggal 27

Novenber 2019

\begin{abstract}
Abstrak
Mitigasi menegang peranan yang sangat vital dalam manajemen bencana sebab jika ancaman bahaya berhasil dicegah maka tidak perhu ada lagi respon bencana berketanjutan. Penelitian ini menggunakan stzdi literatur dengan metode kontparatif dimana objek kajiannya adalah pelibatan dan pertukaran sumberdaya antar aktor dalam langkah mitigasi di wilayah yang memiliki potensi bencana alam serta pernah mengalami kejadian bencana dengan menggtmakan perspektif adaptive governance. Hasil penelitian menumjakkan bahwa stakeholders dalan mifigasi bencana verada dalam dua dimensi yaitu dimensi verikal dan horizontal dengan motif dan isu yang beragam dimana terdapat ketimpangan pelibatan aklor dalam struktur dan jaringan. Wallawsil, Sumberdaya tidak berhasil didistribusikan secara ideal dan secara langsung mempengaruhi konsensus dan komitmen masing-masing stakeholder datan mensinergikan kegiatanmya dengan kerangka mitigasi bencana. Kondisi ini menjadikan pemerintah sebagai teading sector sangat tidak adaptif
\end{abstract}

Kata Kunei: Mitigasi, Multistakeholder, Manajemen Bencana

\begin{abstract}
Mitigation ptass a very vital role in management because disaster is successfully prevented so there is no need for a sustainable disaster response. This study uses a titerature study with a comparative method where the object of study is the involvement and funding of resources between actors in mitigation measures in areas that have the potential for natural disasters and have ever remedied the problem of disasters by using an adaptive governance perspective. The results showed that the stakelzolders in verada disaster mitigation in two dimensions, namely the wertical and horizontal dimensions with diverse motives and issues where there are differences in the imolvement of actors in the strncture and network. As a result, Resources were not strccessfully allocated ideally and directly affected the consensus and comunitment of each stakeholder in synergizing thelr activilles by increasing disaster mitigailon. This condition makes the government as a leading sector that is not very adaptive
\end{abstract}

\section{Keywerds: Mitigation, Multistakeholder, Disaster Management}

\section{PENDAHULUAN}

Potensi bencana merupakan akumulasi dari kerentanan daerah terhadap tingkat kerawanan atau ancaman bahaya yang ada sehingga Undang-Undang Nomor 24 Tahun
2007 memberikan definisi terhadap kejadian bencana sebagai peristiwa atau rangkaian peristiwa yang mengganggu kehidupan manusia seria mengakibatkan kerusakan lingkungan dan kerugian harfa benda serta membawa dampak psikologis. 
Mitigasi bencana telah lama menjadi fokus kajian multisektoral di berbagai Negara, sedangkan di Indonesia, meskipun secara geografis memiliki tingkat kerentanan lingkungan serta statistik bencana yang cukup tinggi, Undang-Undang kebencanaan justru baru disahkan pada tahun 2007 yakni dengan kehuarnya Undang-Undang Nomor 24 Tahun 2007 tentang Penanggulangan Bencana, padahal dalam aksi dan manajemen penanggulangan bencana, tahap mitigasi memegang peranan yang sangat vital.

Dalam hubungannya dengan administrasi publik, apapun bentuknya, bencana selalu membawa derita, menimbulkan korban harta dan nyawa, menghancurkan tatanan sosioekonomi, membentuk pribadi-pribadi yang traumatis dan banyak hal lain yang mengindikasikan kerentanan kolektif sebuah bangsa. Seringnya situasi bencana melanda kondisi masyarakat, menjadikannya sebagai common and public problem yang menuntut kehadiran tindakan intervensi kolektif sebagaimana menjadi domain administrasi publik. Sebagai pola tindak imtervensi yang kolektif, administrasi publik dituntut mampu memainkan peran yang menjadi tanggung jawabnya dalam manajemen bencana. Pertama, administrasi publik turut bermain secara praktis maupun normatif-regulatif (melalui instrumen kebijakan) dalam berbagai aktivitas pemanfaatan sumber daya; kedua, adminisirasi publik bertanggung jawab langsung maupun tidak langsung terhadap situasi yang menciptakan kerugian pada masyaraka; ketiga, administrasi publik bertanggung jawab langsung untuk memberikan perlindungan, penanganan, dan melakukan pencegahan atas berbagai kemungkinan dampak bencana kepada masyarakat (Ulum, dkk : 2008).

Meskipun demikian, mengenai peran serta administrasi publik dalam mitigasi bencana, bayak literatur tidak memberikan penekanan pada pendekatan government, melainkan pada pendekatan governance. Penekanan terhadap konteks governance, dikarenakan secara faktual, pemerintah tidak memiliki kapasitas yang mampu mengimbangi kompleksitas manajemen bencana jika bekerja secara tunggal, terutama bagi negara berkembang dimana pada akhimya, setiap bencana akan memunculkan daftar panjang gugatan terhadap peran dan tanggung jawab dari berbagai pihak yang memiliki otoritas dan peran dalam tata kelola pemerintahan. Ironisnya, pada setiap bencana yang terjadi, kita hampir selalu dihadapkan pada tuduhan terhadap buruknya kinerja birokrasi dalam aksi manajemen bencana. Respons yang lambat, pengambilan keputusan dan tindakan yang reaktif dan parsial, operasi yang tidak terkoordinasi, aksi formalistik-simbolik bahkan melempar tanggung jawab, merupakan etos dan perilaku faktual birokrasi dalam upaya menghadapi bencana (Ulum, dkk : 2008).

Kerumitan masalah semakin mencapai klimaks ketika penanganan bencana menuntut kejelasan pihak yang harus dimintai pertanggungjawaban beserta siapa saja pihak yang harus dilibatkan dalam kerangka kerja koordinatif yang terpadu dan jelas tugas dari masing-masing aktor. Tidak jarang, ego sektoral sering mendominasi dalam kerangka ini. Belum lagi tarik ulur kepentingan dari sektor-sektor penopang governance lainnya yang rentan dengan praktik kolusi. Di Indonesia, masalah tersebut masih dominan sehingga tidak dapat dihindari bahwa seringkali, ada ketidakjelasan tindak penanganan bencana, kelambanan tindakan yang juga memberi peluang bagi upaya untuk lari dari tanggung jawab, kondisi mismanagement dan miskoordinasi karena kerap kali dibangun tanpa kejelasan tanggung jawab antar aktor. Musdah (2014). Selain menghadapi problem rendahnya kualitas kinerja penanganan bencana, terdapat problem lain yang juga merefleksikan tindakan pemerintah terkait dengan bencana yang terjadi, yaitu basis tindakan yang hanya berorientasi pada upayaupaya penanganan pasca bencana. Tindakan yang dilakukan pemerimtah terkesan merupakan aksi spontan yang terlambat dan kurang terorganisasi dengan baik.

\section{TINJAUAN PUSTAKA}

\section{Penanggulangan Bencana}

Terdapat beberapa pengertian bencana yang diungkapkan baik oleh para ahli maupun oleh lembaga tertentu namun Undang-Undang 
Nomor 24 Tahun 2007 mendefinisikan bencana sebagai peristiwa atan rangkaian peristiwa yang mengancam dan mengganggu kehidupan dan penghidupan masyarakat yang disebabkan, baik oleh faktor alam dan/atau non-alam maupun faktor manusia sehingga mengakibatkan timbulnya korban jiwa manusia, kerusakan lingkungan, kerugian harta benda, dan dampak psikologis.

Dari definisi, dapat ditarik beberapa kriteria bencana yaitu:
a. Peristiwa/kejadian atau rangkaian peristiwa
b. Mengancam dan mengganggu kelridupan dan penghidupan masyarakat
c. Disebabkan oleh alam, manusia ataupun perpaduan antara mranusia dengan alam
d. Menimbulkan korban jiwa, penderitaan, kerugian harta benda, kerusakan lingkungan, kerusakan sarana dan prasarana, dan dampak psikologis
e. Terjadi secara tiba-tiba.

\section{Upaya Penanggulangan Beneana}

Terdapat berbagai pendapat tentang siklus atau tahap penanggulangan bencana, mulai dari yang paling sederhana sampai yang paling kompleks. Dalam kondisi tidak terdapat potensi bencana, Undang-undang 24 Tahun 2007 secara unum membagi penanggulangan bencana ke dalam tiga tahap dan upaya penangguangam yaitu; Pertamas prabencana terdiri dari perencanaan penanggulangan bencana, pengurangan risiko bencana, pencegahan, pemaduan dalam perencanaan pembangunan, persyaratan analisis risiko bencana;, pelaksanaan dan penegakan rencana tata ruang, pendidikan dan pelatihan; dan persyaratan standar teknis penanggulangan bencana. Sementara dalam kondisi terdapat potensi bencana terdiri dari mitigasi, peringatan dini dan kesiapsiagaan.

\section{Mitigasi Beneana}

Meskipun telah dinyatakan bahwa tidak ada strategi baku dalam mitigasi bencana, beberapa pihak mengungkapkan strategistrategi yang umum dipakai dalam mitigasi bencana. Menurut Schwab dkk (2007), terdapat enam metode dalam mitigasi bencana yaitu Building Standards, Development regulations,
Capital improvement program, Land and property acquisition, Taxation and fiscal policies, dan Publik awareness.

Selain strategi yang telah disebutkan di atas, salah satu yang cukup popular dalam banyak kajian oleh akademisi dan jamak diterapkan pada sebagian besar pemangku kepentingan dalam urusan bencana adalah strategi Total Disaster Risk Management (Stockholm Reciliance Centre, 2013) yaitu:

1. Establishment of coordination mechanism and legal framework for disaster reduction.

2. Integration of disaster reduction concept into development planning.

3. Improvement of sharing and management.

4. Promotion of Education and Publik Awareness.

5. Development of multi-stakeholder and citizen partnership.

\section{.Adaptive Governance}

Adaptive governance merupakan pendekatan dalam melihat kebijakan pengelolaan dalam situasi yang kurang dapat diprediksi sehingga menuntut proses-proses yang dinamis dalam proses kebiakan publik. Secara sederhana, dapat pula dikatakan bahwa adapative governance merupakan bagian konsep dari teori institusional yang berfokus pada evolusi dari institusi formal dan informal untuk pengelolaan asset bersama seperti sumberdaya alam dan asset lingkungan yang menyediakan jaringan ekosistem (Brumer et al, 2005)

Dalam literatur lain menjelaskan bahwa gagasan adaptive governance muncul dari ideide tentang ekonomi politik, sumber daya alam, teori ekonomi, teori organisasi, teori sistem dan co-management dan ilmu sains yang kompleks sehingga dalam memahami gagasan ini kerap kali dikaitkan dengan posisi stakeholders sebagai unsur perting dalam proses kajiannya (Hatfileds-Dodds et al, 2005)

Selanjutnya, Berkes dan folke (2008) memberikan setidaknya terdapat 3 fitur dalam menilai adaptive governance yaitu 
1. Motivasi dan Isu,

Motif merupakan dorongan untuk berpartisipasi ataupun bertindak dalam adaptive governance hal ini sangat dipengaruhi oleh kepentingan yang dapat mentpengaruhi keputusan untuk memasukkan isu-isu multidimensional baru dalam kegiatan dan tindakan kolektif,

2. Struktur

Adaptive governance membutuhkan system koordinasi dan kerjasama seluruh dimensi jaringan horizontal dan vertical. Hal ini juga berpengarul pada proses pengambilan keputusan dan networking dengan demikian proses ini mengacu pada partisipasi dan kerjasama multistakeholders dalam berbagi informasi dan sumberdaya

3. Jaringan

Jaringan horizontal menurut sektor (swasta, NGO dan Pemerintah) serta jaringan vertikal (multilevel government) yang mempengauhi pertukaran sumber daya yang dimiliki oleh masing-masing stakeholders

Dalam kerangka ekologis dan mitigasi bencana, adaptive governance dapat dipandang sebagai pendekatan dalam menganalisis hal yang berhubungan dengan ketidakpastian situasi dalam membangum ketahanan yang relevan dengan analisis kondisi penanggulangan bencana.

\section{METODE PENELITIAN}

Tulisan ini merupakan hasil dari studi literatur dengan metode komparatif dimana objek kajianmya adalah pelibatan dan pertukaran jaringan antar aktor dalam langkah-langkah mitigasi di wilayah yang memiliki potensi bencana alam serta pernah mengalami kejadian bencana. Data penelitian dikumpulkan dengan mengacu pada beberapa publikasi penelitiam bertema serupa.

\section{HASIL DAN PEMBAHASAN}

\section{Dimensi aktor}

Sejalan dengan korteks peranan dan pelibatan multistakeholder, Berkes dan Folke
(2008) dalam Mingiomi (1991) membagi keterlibatan multistakeholder menjadi 2 Dimensi. Dimensi pertana merupakan Dimensi horisontal yang terbagi dalam 3 sektor yaitu: Pertama, Civil sector (sektor sipil), yang merupakan organisasi di luar pemerintah seperti komunitas masyarakat, NGO dan akademisi yang beckontribusi terhadap kepentingan pablik. Keberadaan NGO dalam dalam konsep governance merupakan bagian yang vital dan menjadi kunci dari beberapa preposisi penting guna mewujudkan governance menekankan kepada keterlibatan aktor-aktor institusional yang berasal dari luar tubuh pemerintah (UNDP, 1994). Stakeholder lainmya yang memiliki peran signifikan adalah para akademisi yang melakukan beragam aktifitas ilmiah baik dari sudut pandang ilmu eksakta maupun ilmu sosial. Mitigasi bencana merupakan langkah-langkah yang membutuhkan landasan ilmiah serta memposisikan keseimbangan antara sektor fisik dan sektor sosial dalam perancanaan starteginya.

Kedua, Private Sector (sektor privat/swasta), merupakan perusahaan atau pihak swasta lainnya yang memiliki kepentingan terhadap objek lingkungan dimana pihak ini memiliki pernanan dalam mengeksplorasi dan eksploitasi sumberdaya alam yang mampu memperbesar kondisi kerawanan di zona bencana, Sektor ini didefinisikan sebagai pihak-pihak yang memiliki aktifitas produksi yang sifatnya massif mengeksploitasi sumberdaya alam. Meskipun banyak diasumsikan dapat memberikan efek negatif pada kelangsungan lingkungan hidup, namun term governance memberikan penekanan terhadap adanya pelibatan sektor swasta dalam setiap arah kebijakan Negara. Hal tersebut tentu saja tidak terlepas dari paradigma modernisasi dalam kajian-kajian pembangunan yang sedikit banyak berorientasi pada tercapainya status watfare state dengan mendorong fungsi-fungsi industrialisasi pada sektor ekonomi hingga pada akhirnya sektor privat sebagai pelaku ekonomi menjadi unsur penting dalam arah pembangunan Negara. Paradoks industrialisasi dan perlindungan lingkungan hidup pada akhirnya menjadikan sektor privat menjadi pihak yang memiliki 
peranan yang sangat vital dalam kajian mitigasi bencana.

Ketiga, Public Sector (sektor publik), terdiri dari pihak-pihak yang memiliki kepentingan publik seperti pemerintah dan badan-badan milik pemerintah sebagai institusi pembuat kebijakan. Pembuatan kebijakan disini tidak termasuk pada proses-proses legislasi melinkan instansi pemerintah yang areal kerjanya terkait dengan mitigasi bencana Ragam kepentingan kategori ini dapat mebuat rumitnya upaya mitigasi, mengingat bahwa masing-masing dari instansi ini memiliki dasar hukum dan panduan operasional yang berbedabeda sehingga dapat menyulitkan leading sektor dalam memaksimalkan fungsi dan langkah mitigasi jika tidak tercapai kesamaan persepsi dan koordinasi yang baik dalam langkahlangkah mitigasi.

\section{Dimensi Vertikal}

Dimensi kedua yaitu Dimensi Vertikal. Dalam dimensi ini, keberadaan stakeholder dipandang sebagai kesatuan organisasi dan dilihat dari seberapa besar ruang lingkup dan jaringan kerja organisasi tersebut. Dimensi vertikal terbagi menjadi 4 jenis yaitu:

1. Local and operational: dilihat pada tingkat kelembagaan pada skop terkecil dimana stakeholders tersebut hanya bergerak pada proses pengelolaan ataupun hanya bergerak dalam ranah operasional. isu-isu teknis yang kenudian kerap menjadi fokus dari kepentingannya. Selain itu kategori ini juga sangat lemah dalam akses terhadap proses pembuatan kebijakan sehingga pada umumnya bergerak dalam konteks pemberdayaan masyarakat dan keterlibatan dalam program-program spesifik.

2. Regional and collective, merupakan stakeholder yang didefinisikan sebagai stakeholders yang memiliki akses langsung terhadap kebijakan dan memilik pengaruh yang besar dalam objek mitigasi bencana. Meskipun dalam proses policy making memiliki kekuatan dalam menetapkan panduan dan konsensus bensama, stakeholders ini tidak memiliki kewewenangan langsung dalam mendiktekan program-program spesifik dan senantiasa harus berkoordinasi dengan pihak-pihak lain dalam level yang sama.

3. National and constitutional, merupakan level stakeholders yang mempunyai kekuatan dalam membuat ataupun merubah kebjjakan. Stakeltolder ini memiliki jaringan dan otoritas yang cukup besar dalam menentukan payung hukum monajemen bencana bencana

4. International levels, didefinisikan sebagai aktor-aktor internasional sebagai dasar dan rujukan praktis dan teoritis. Meskipun tidak memiliki akses terhadap pembuatan kebijakan ataupun pertudang-undangan negara namun keberadaannya memberikan dampak bagi kaidah-kaidah ilmiah maupun standar intemasional penanggulangan bencana dalam konteks global manajemen bencana.

\section{Motif dan Isu Sektoral}

Salah satu poin penting dalam pemetaan stakeholder mitigasi bencana adalah identifikasi sektor dan motivasi. Motivasi sektoral sangat mempengaruhi kapasitas inisiatif leading sector untuk memasukkan isu-isu baru dan berubah menjadi wacana kebijakan pun tindakan kolektif, baik bersifat ekologi, ekonomi, sosial budaya atau perkembangan aksi kolektif. Dalam situasi yang berbeda, stakeholder yang berbeda juga mungkin memiliki motivasi yang berbeda untuk mengambil bagian dalam tindakan kolektif.

Pada tabel berikut dipetakan sektor yang ada sebagai stakeholder dengan motif dan isu strategis yang menjadi area peranannya dalam mitigasi bencana. Peta stakeholder ini selain memunjukkan luasnya konteks mitigasi bencana dalam perspektif multisektor, juga dapat menjadi acuan dalam menyusun alur dan jejaring stakeholder mitigasi beneana. 
Tabel 1

Motif dan Isu Strategis Masing-Masing Stakeholder dalam Kerangka Multistakholders Mitigasi Bencana

\begin{tabular}{|c|c|c|}
\hline Sektor & $\begin{array}{l}\text { Motif untmk terlibat dalam tindakan } \\
\text { mitigasi }\end{array}$ & $\begin{array}{c}\text { Isu yang Umumnya menjadi fokus dari } \\
\text { srakehelders }\end{array}$ \\
\hline Sipall & $\begin{array}{l}\text { - } \text { Ekonomi } \\
\text { - Perlindungan lingkungan } \\
\text { - } \text { Penanfaatan SDA } \\
\text { - Historis } \\
\text { - } \text { Adat dan kebudayaan } \\
\text { - } \quad \text { Spendídikan } \\
\end{array}$ & $\begin{array}{l}\text { - Mata pencaharian turun temurun } \\
\text { - } \quad \text { Lahan Adat } \\
\text { - } \quad \text { Kesenjangan Pendapatan } \\
\text { - Warisan adat dan budaya } \\
\text { - Penelitian dan Pengkajian }\end{array}$ \\
\hline Privat & $\begin{array}{ll}\text { - } & \text { Profit } \\
\text { - } & \text { Ketenagakerjaan } \\
\text { - } & \text { Tuntutan UU }\end{array}$ & $\begin{array}{l}\text { - Perluasan areal produksi } \\
\text { - Perambahan jumlah wisatawan } \\
\text { - Pembangunan infrastruktur pariwisata } \\
\text { - Penyerapan tenaga kerja } \\
\text { - Pajak } \\
\text { - CSR }\end{array}$ \\
\hline Publik & 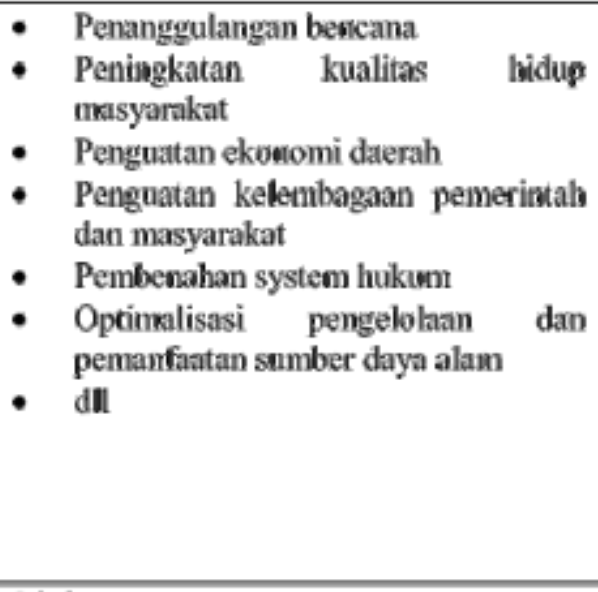 & $\begin{array}{l}\text { - Isu Historis Kebencanaan } \\
\text { - Belum optimalinya pemanfaatan SDA secara } \\
\text { berkelanjutan } \\
\text { - Belum optionalnya keberlanjutan pengelolaan } \\
\text { dan pemanfaatan sumber daya air } \\
\text { - Belum adanya gerakan bersama dakam } \\
\text { optimalisasi fungsi sumber daya hoian } \\
\text { - Masih kurangnya pemahaman tentang } \\
\text { mekanisme kepernilikan dan konsolidasi } \\
\text { pemanfaatan lalran } \\
\text { - Belum jelasnya batas-batas pengelolaan hutan } \\
\text { Belum teridentifikasinya potensi sumber- } \\
\text { sumber daya mineral daerah } \\
\text { - pemanfatan SDA lintasdaerah }\end{array}$ \\
\hline
\end{tabular}

Sumber : Hasil Olah Data

Undang-undang nomor 24 tahun 2007 tentang penanggulangan bencana melalui pasal tentang asas dan prinsip penanggulangan bencana menekankan pada koordinasi dan kerjasama lintas stakeholder dalam penyelenggaraan penanggulangan bencara. Selain itu dalam pasal tentang tujuan dan penggulangan bencana secara gamblang $U U$ ini juga memberikan gambaran bahwa penanggulangan bencana harus diupayakan dengan membangun partisipasi dan kemitraan antara publik dan swasta. Dengan melihat beragamnya motif sektoral tidak jarang bahkan bisa dikatakan hapir setiap kali aksi mitigasi berursan dengan kepentingan sektoral

\section{Struktur dan Jaringan Mitigasi}

Siruktur dan jaringan yang mendukung koordinasi dan kerjasama seluruh dimensi aktor dalam mitigasi bencana. Istilah struktur (structure) dalam hal ini mengacu pada proses pengambilan keputusan dan jaringan (network) bertujuan untuk pemecahan masalah dalam implementasi kebijakannya. Dengan demikian, konsep ini berfokus pada proses partisipasi deliberatif dalam membangun konsensus dengan tujuan meningkatkan kerja sama dan koordinasi antara berbagai pemangku kepentingan yang mewakili kebutuhan dan kepentingan stakeholder pada tingkat yang berbeda.

Koordinasi ini juga dapat ditingkatkan dengan pengembangan pembelajaran yang mentransfer pengetahuan dan pendekatan baru dalam cross-sector collaboration. Dalam sistem adaptif yang kompleks, ini juga mendorong dialog yang akhirnya dapat memunculkan pengetahuan baru. Sejauh mana inisiatif leading sector dapat membangun forum untuk 
koordinasi kegiatan manajemen juga dapat memberikan indikasi kapasitas adaptasi mereka. (Hidayat, 2014)

Berdasarkan hal tersebut, maka struktur dan jaringan yang terbentuk berdasarakan perspektif multistakeholders dalam mitigasi bencana dapat dilihat dari analisis tipe-tipe pelibatan, tanggungjawab, fungsi dan sumber daya masing-masing stakeholders.

Tabel 2: Tipe Pelibatan, Tanggungjawab, Fungsi dan Sumber Daya Sektoral

\begin{tabular}{|c|c|c|c|c|}
\hline Stakeholders & Tipe Kerjasama & $\begin{array}{c}\text { Tipe } \\
\text { Tanggung } \\
\text { Jawab }\end{array}$ & Fungsi & Sumber daya \\
\hline Sipil & $\begin{array}{l}\text { Konsultasi dan } \\
\text { partisipasi }\end{array}$ & sukareha & $\begin{array}{l}\text { dukungan akademis dan } \\
\text { gembaran faktual pada } \\
\text { Pengawasan } \\
\text { pelaksanaan }\end{array}$ & Skill dan penyedia informasi \\
\hline Privat & Koordinasi & wajib & $\begin{array}{l}\text { Pemberdayaan areal } \\
\text { eksplorasi }\end{array}$ & $\begin{array}{ll}- & \text { Rencana eksplocasi } \\
- & \text { Program pemberdayaan } \\
- & \text { Dana pemulihan } \\
- & \text { Teknologi } \\
- & \text { Tenaga ahli }\end{array}$ \\
\hline Publik & $\begin{array}{l}\text { Leading sektor, } \\
\text { pembanguman } \\
\text { lintas sektoral }\end{array}$ & wajib & $\begin{array}{l}\text { Pembuat dan pelaksana } \\
\text { kebijakan, pengawasan }\end{array}$ & $\begin{array}{l}\text { Kebijakan, perizinan, anggaran, } \\
\text { sanksi }\end{array}$ \\
\hline
\end{tabular}

Sumber : Hasil Olah Data

Gambar 1: Skema Struktur dan Tipe Pelibatan dalam Jaringan Mítigasi

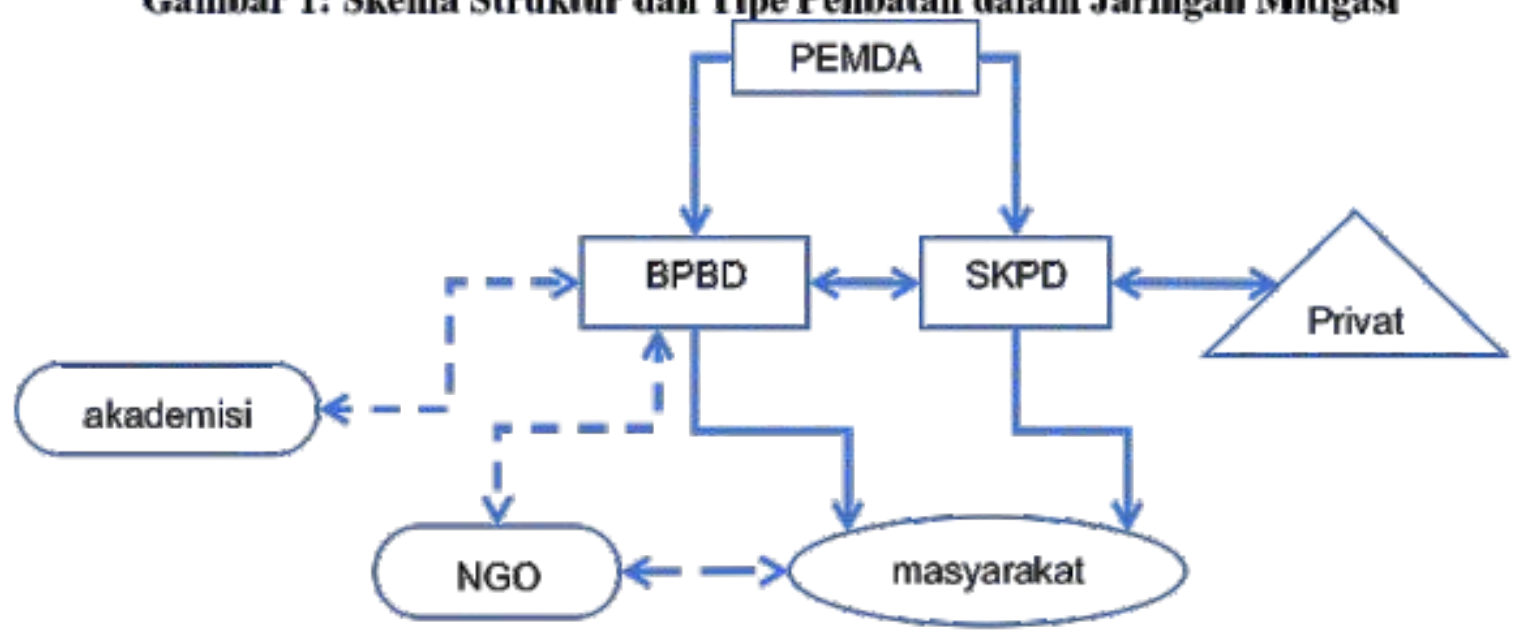

Keterangan

$\longleftrightarrow$; pelibatan koordinatif (hubungan saling mempengaruhi kebijakan)

4........ : pelibatan konsultatif (penting namun lemah dalam mempengaruhi kebijakan

Sumber: Purna (2016)

: pelibatan Instruktif (pelaksana dan objek)

Gambar diatas menjelaskan bahwa Pemerintah Daerah merupakan leading sector dalam kerangka mitigasi bencana dimana BPBD dan SKPD merupakan sektor kunci sebagai eksekutor antara antara BPBD yang menangani isu kebencanaan dan SKPD yang mengatur tenfang program yang bersentuhan dengan daerah rawan bencana, SKPD merupakan pintu masuk bagi sektor privat (swasta) dalam melakukan eksplorasi dan eksploitasi SDA di daerah rawan bencana yang memilik hubungan koordinasi dan saling mempengaruhi satu sama lain. Sementara itu, akademisi dan NGO (LSM) sebagai sektor yang sangat vital bagi manajemen bencana hanya terkoneksi dalam kapasitas sebagai konsultan 
yang tidak memiliki kekuatan besar dalam mempengaruhi praktik manajemen kebencanaan padahal akademisi memberikan banyak data ilmiah mengenai kondisi bencana, sementara NGO merupakan sektor yang paling sering dan intens mendampingi masyarakat dalam zona bencana. Sementaca ifu, BPBD dan SKPD kerap kali memposisikan masyarakat sebagai objek dari kebijakan dan peraturan yang ada.

Pelibatan stakeholders dalam penanggulangan bencana kerap kali menjadi masalah yang menjadi hambatan serius. Terlalu banyak pihak yang terlibat menimbulkan kesulitan tersendiri dalam pembagian peran masing-masing pelaku. Hal ini disebabkan antara lain dapat dilihat dalam 6 hal yaitu:

1. persaingan dalam mendapafkan sumberdaya,

2. ketakutan akan adanya pengaruh terhadap otonomi lembaga,

3. perbedaan visi antar lembaga,

4. kurangnya inisiatif dari kepemimpinan

5. kepentingan sektor privat dalam areal bencana

6. intervensi politik tentang masalah zonasi

Pelibatan model koordinasi sejatinya menuntut tanggung jawab penuh pada fungsi dan peranan stakeholder dalam platform kerjasama oleh karena itu dalam platform ini, pilak swasta memiliki kewajiban dalam melakukan aktifitasnya berdasarkan alur yang telah ditetapkan bersama. berbeda dengan sektor sipil yang memiliki keterikatan secara sukarela sebagai akibat dari model pelibatan yang bermain dalam ranah konsultasi selain dari kewajiban tunduk pada perundang-undangan, pihak swasta juga terikat pada standar internasional penjaminan mutu terhadap layanan publik serta prinsip usaha yang memperhatikan kelestarian lingkungan. Dalam pelibatan jenis koordinasi, selain berkewajiban dan senantiasa terikat pada platform, model koordinasi juga mendekatkan stakeholders pada akses langsung terhadap pembuatan kebijakan ataupun kekuatan datam menentukan design program berkelanjutan.

Berdasarkan sudut pandang tersebut dan model pelibatan yang berbeda antara sektor privat dan sektor sipil, dapat ditarik kesimpulan bahwa dalam konflik yang mungkin saja terjadi akibat benturan kepentingan, posisi sektor swasta akan lebih diuntungkan mengingat sektor ini memiliki motif dan isu yang sama dengan sektor publik serta akses yang lebilh dekat dengan proses legislasi dikarenakan hubungan langsungnya dengan SKPD tekait.

Meskipun BPBD merupakan leading sektor namun pada kenyataannya dalam ranah formal pengambilan kebijakan, kewenangan pada pengambilan keputusan masih memiliki keterikatan struktural dengan SKPD tertentu mengingat bahwa platform penanggulangan bencana harus yang harus sesuai dengan arah pembangunan daerah artinya, jika dilihat dari motif dan isu yang dibangun oleh sektor publik maka dapat dilihat bahwa struktur yang terbentuk justru mengurangi power yang dimiliki oleh BPBD dalam menentukan keputusan strategis mitigasi bencana. Kondisi tersebut juga diperparah dengan kondisi bahwa BPBD tidak memiliki koneksi langsung terhadap sektor privat dalam mendiktekan langkah-langkah mitigasi. Akibatnya, sektor privat kerap kali melakukan aktivitas penanganan bencana tanpa melihat perencanaan mitigasi yang dibentuk oleh BPBD.

Ketimpangan pada distribusi power pada struktur yang besar dapat diamati pada sektor sipil dimana Sektor ini merupakan sektor yang paling kehilangam power dalam menentukan arah kebijakan. Jika dilihat dalam struktur yang terbentuk, pada kenyataannya sektor sipil masilh ditempatkan sebagai objek kebijakan ataupun "pihak ketiga" dalam platform mitigasi. Situasi ini akan menghambat proses konsensus yang kelak akan disepakati bersama. Ketidakseimbangan situasi ini juga dikatakan sebagai penyebab ufama terhambatnya transfer pengetahuan dam berefek pada lemahmya respon pemerintah dalam membaca isu strategis. Situasi ini jelas mengindikasikan lemahnya tingkat adaptasi pemerintah sebagai leading sector.

Pertukaran sumber daya dalam jaringan ditentukan oleh posisi masing-masing stakeholder dalam struktur yang dibentuk dan mempengaruhi kewajiban stakeholder dimana semakin kuat posisi stakeholder maka semakin terikat stakeholder tersebut untuk distribusi 
sumber daya dalam rangka memproduksi pengetahuan baru dan konsensus yang terbentuk.

Lemalmya pertukaran sumber daya antar masyarakat ditandai dengan penempatan masyarakat sebagai objek program dan pendidikan mitigasi serta lemahnya pengetahuan pemerintah terhadap isu strategis yang dimiliki oleh masyarakat terutama nlainilai ekologi dalam kultur masyarakat. Padahal dalam konteks isu strategis tentang lingkungan juga masyarakat lokal memiliki kepentingan ekonomi dan cultural yang hendaknya harus dipahami oleh leading sektor sebagai prioritas dalam strategi mitigasi. Hal tersebut dikarenakan masyarakat merupakan pihak yang akan mendapatkan dampak langsung dari bencana. Praktik zonasi yang tidak memperhatikan nilai-nilai kemasyarakatan merupakan salah satu contoh lemahnya leading sektor dalam melihat sumber daya yang di miliki oleh masyarakat.

Dalam aktivitas mitigasi, tanggung korporasi swasta terutama yang secara langsung berhubungan dengan pemanfaatan sumber daya alam dan lingkungan adalah transparansi rekam jejak operasional dan akuntabilitas atas setiap aktivitas fisik eksplorasi lingkungan. Berdasarkan pembahasan sebelumnya diketahui bahwa sektor privat memiliki kepentingan pengembangan eksplorasi dalam beberapa tahun ke depan oleh karena itu penyediaan reneana pembangunan berkelanjutan menjadi tanggung jawab pihak pengelola dalam mendukung upaya mitigasi bencana namun sampai saat imi sangat jarang ditemukan dokumen rencana eksplorasi privat yang diajukan dan dipertimbangkan oleh instansiterkait. Kondisi ini dapat melemahkan perancangan strategi mitigasi bencana karena lingkungan hidup bukanlah merupakan areal yang otonom dalam sebuah zona melainkan satu kesatuan ekosistem dimana efek kecil nampu berdampak pada keseluruhan sistem.

Korporasi bertanggung jawab memberi kompensasi atas segala dampak yang ditimbulkan dari aktiviras bisnisnya baik secara langsung kepada masyarakat maupun yang berupa konservasi dan rehabilitasi lingkungan.
Selain itu, Komitmen swasta/korporasi perlu terus ditingkatkan melalui implementasi Corporate Social Responsibility (CSR) atau kegiatan sosial masyarakat yang dapat dilakukan dalam berbagai bentuk. Dukungan yang diberikan dapat berupa dana (modal), pinjaman, biaya promosi, tenaga (bimbingan teknis dari tenaga ahli), peralatan/teknologi, atau akses informasi seputar disaster knowledge.

Implementasi CSR hingga kini jelas masih jauh dari yang dilrarapkan. Masalah ada sebab persepsi korporat yang menganggap bahwa alokasi dana untuk kepentingan CSR sebagai beban tersendiri karena merupakan faktor biaya. Di samping itu, korporat sudah merasa cukup bertanggung jawab dengan membayar pajak yang hasilnya digunakan untuk pembangunan. Padahal, beberapa hasil kajian menunjukkan adanya korelasi positif antara profit dan CSR, atau tujuan finansial dan tujuan sosial perusahaan.

Perusahaan yang mencatat laba tertinggi adalah para pionir dalam CSR. Meskipun dalam praktiknya sesuai dengan tuntutan perundangundangan, sektor privat memiliki tanggung jawab pendanaan terhadap menajemen bencana berbentuk dana hibah kebencanaan, namun dana tersebut dialokasikan pada situasi tanggap darurat serfa rekonstruksi pasca bencana bukan pada tahapan mitigasi dan pencegahan bencana.

Ironisnya, selama ini realitas yang terjadi memperlihatkan bahwa daerah-daerah tambang yang kaya sumber daya mineral di mana perusahaan-perusahaan tambang besar dunia (Freeport di Papua dan Newmont di Minahasa) beroperasi justru menjadi kantong-kantong kemiskinan masyarakat lokal, pusat konflik bernuansa kecemburuan sosial, serta sumber perusakan lingkungan dan sumberdaya alam. Hal tersebut menjadi bukti masih diabaikannya etika dan tanggung jawab sosial yang seharusnya menjadi pionir dalam CSR.

Sektor publik setidaknya memiliki sumberdaya terbesar berupa kebijakan dan sanksi dalam konsensus serta pemberdayaan masyarakat. Dengan adanya fungsi kebijakan dan sanksi yang dimilik pemerintah juga juga 
dapat menindak oknum-oknum yang yang ditemukan telah melanggar konsensus bersama ataupun peraturan hukum yang ada urtuk kepentingan mitigasi bencana. Sumber daya imi juga dituntut untuk didistribusikan secara merata berdasarkan tahapan policy making agar tidak berat sebelah dan cenderung merugikan pihak tertentu terlebih lagi mengingat realitas tipe pelibatan yang tidak setara antar masingmasing sektor. Selanjutnya, Pemberdayaan masyarakat memiliki peranam besar dalam konteks mitigasi bencana alam. Selain mengurangi kondisi kerawanan, mitigasi juga berfokus pada kondisi kerentanan masyarakat baik itu kerentanan sosial maupon kerentanan ekonomi oleh karena itu peran-peran program pemberdayaan masyarakat sangat dibutuhkan dalam meningkatkan ressiliance dalam upaya memperkecil jarak antara kerentanan masyarakat dan kerawanan beneana selain pengadaan dan penggunaan teknologi mitigasi menjadi salah satu sumber kesuksesan mitigasi.

\section{Penutup}

Stakeholder terbagi dalam dua dmensi yaitu; yang pertama dimensi horisontal yang melihat stakeholders berdasarkan motif dan isu yaitu sektor publik yang merupakan lembaga pemerintah, sektor privat yang merupakan Badan Usaha milih dan sektor sipil yang merupakan masyarakat baik lembaga masyarakat ataupun NGO atan kelompok akademisi, dan kedua dimensi vertikal yang melihat dari besar areal kewenangan. Motif dan Isu yang beragam dari masing-masing stakeholders kemudian membentuk struktur dan jaringan pertukaran sumberdaya pada mitigasi dalam kerangka aksi multistakeholders dimana ketimpangan struktur dan jaringan secara langsung mempengaruhi pertukaran sumber daya, ahirnya masing-masing sumber daya tidak berhasil didistribusikan secara ideal. Kondisi ini secara langsung mempengaruhi konsensus dan komitmen masing-masing stakeholder dalam mensinergikan kegiatannya dengan kerangka mitigasi bencana. Ketimpangan pengakomodasian isu yang tidak berimbang dan tampak pada struktur dan jaringan multistakeholder menjadikan pemerintah sangat tidak adaptif dalam memformulasikan kebijakan mitigasi bencana.

\section{DAFTAR PUSTAKA}

Berkes dan Folke. (2008). Linking Social and Ecological Systems: Management Practices and Social Mechanisms for Bullding Resilience, Cambridge: Cambridge University Press.

Berkes, Colding and Folke. (2003). Navigating sacial-ecological systems: Bullding resilience for complexity and change. Cambridge: Cambridge University Press.

Berkes, F. (2008). Commons in a multi-level world. International Journal of the Commons

Brunner, et al.(2005). Adaptive Governance: Integrating science, policy and decision making, New York: Columbia University Press.

Hatfield Dodds et al. (2005). The Role of Social Capital in Sustainable Dewelopment Assessment Frameworks, International Journal of Enviromment, Workplace and Employment

Hidayat, Rahmat. (2014). Jaringan Kebijakan Pada Proses Perumusam Kebijakam Masyarakat Adat Ammatoa Kajang, Makassar: (Tesis) Universitas Hasamuddin.

Mingioni, E. (1991). Fragmented societies. The saciology of economic life beyond the market paradigm. Basil Blackwell, Oxford, UK

Musdah Erwin. (2014). Analisis Mitigasi Nonstruktural Bencana Banjit Luapan Danau Tempe, Yogyakarta: (Tesis) Universitas Muhammadiyah Yogyakarta.

Purna, Zarni Adia, (2016) Strategi Mitigasi Bencana Alam Nonstruktural di Gunmig Bawakaraeng dalam Perspektif Adaptive Governance, Makassar : (Tesis) Universitas Hasanuddin Makassar. 
Schwab dkk. (2007) Hazard Mitigation and Preparedness, United States: Wiley

Stockholm Reciliance Centre. (2013). Insight: Adaptive Governance, Stockholm: Stockholm University Press

Ulum dkk. (2008). Manajemen Bencana Dan Gadjah Mada University Press.

\section{Governance Mind Set, Yogyakarta:}
Cos

Undang-Undang Republik Indonesia Nomor 24 Tahun 2007 tentang Penanggulangan Bencana

UNDP. (1994). Modul Mitigasi Bencana, Edisi Kedua 
